\title{
ЗАСТОСУВАННЯ МЕТОДІВ МОДЕЛЮВАННЯ ДЛЯ МОНІТОРИНГУ ПЕРЕВЕЗЕНЬ ВЛАСНИМИ ПАРКАМИ ОПЕРАТОРСЬКИХ КОМПАНІЙ
}

Канд. техн. наук В.В. Кулешов

\author{
ПРИМЕНЕНИЕ МЕТОДОВ МОДЕЛИРОВАНИЯ ДЛЯ МОНИТОРИНГА \\ ПЕРЕВОЗОК СОБСТВЕННЫМИ ПАРКАМИ ОПЕРАТОРСКИХ КОМПАНИЙ
}

Канд. техн. наук В.В. Кулешов

\section{APPLICATION OF DESIGN METHODS FOR MONITORING OF TRANSPORTATIONS OWN PARKS OF OPERATOR COMPANIES}

\author{
Cand. of Techn. Sciences V. Kuleshov
}

Виконаний аналіз кількості та структури інвентарного і парків вантажних вагонів операторських компаній державної та інших форм власності в Украйні станом на 01.08.2013 p., а також вантажних вагонів в управлінні Украӥнського транспортнологістичного центру. Моделювання моніторингу перевезень власними вагонами парку операторських компаній у взаємодї з інфраструктурою можливо реалізувати у вигляді системи імовірнісних автоматів Мура з детермінованими функціями виходів.

Ключові слова: вагон, власний парк, залізнична адміністрачія, метод імовірнісноавтоматного моделювання, операторська компанія, парк вагонів, перевезення.

Выполнен анализ количества и структуры инвентарного и парков грузовых вагонов операторских компаний государственной и других форм собственности в Украине по состоянию на 01.08.2013 г., а также грузовых вагонов в управлении Украинского транспортно-логистического иентра. Моделирование мониторинга перевозок собственными вагонами парка операторских компаний во взаимодействии $c$ инфраструктурой возможно реализовать в виде системы вероятностных автоматов Мура с детерминированными функииями выходов.

Ключевые слова: вагон, собственный парк, железнодорожная администрация, метод вероятностно-автоматного моделирования, операторская компания, парк вагонов, перевозки.

The analysis of the number and structure of the inventory and freight car fleet operating companies and other forms of state property in Ukraine as of 01.08.2013. Also, the freight cars in the management of Ukrainian transport and logistics center. The issue of improving fleet management systems of their own freight cars is important for further reform of the railway sector in Ukraine. Simulation of traffic monitoring own rolling stock operating companies in conjunction with the infrastructure could be implemented as a system of probability Moore automata with deterministic output functions. The use of modeling techniques for monitoring traffic own parks operating companies in conjunction with the infrastructure in the new conditions possible on the basis of agency agreements with the owners of rolling stock for freight. The Railway Administration may act as a guarantor of quality obligations of agreements (contracts and contracts of carriage of vehicles) as part of the timely organization of cargo transportation and for the submission of the rolling stock for loading. 
Keywords: car, a private park, the railway administration, the method of probabilityautomatic modeling, of operating companies, wagons, carriage.

Вступ. Обсяг вантажоперевезень залізниць України за 9 місяців 2013 р. скоротився на 5,3\% (до 324,55 млн т) у порівнянні з аналогічним періодом 2012 р. Обсяг транзитних вантажів зменшився на $20 \%$ (до 25,1 млн т), а імпортних - на $0,7 \%$ (до 25,7 млн т). Обсяг вантажних перевезень у внутрішньому сполученні за цей же період скоротився на 6,3\% (до 168,9 млн т), але експорт залишився без змін - до 105 млн т. Відомо, що за 2013 р. через скорочення вантажних перевезень неодержано близько 3 млрд грн.

Загальний парк вагонів в Україні станом на 01.08.2013 p. складав 184,7 тис. ваг. Інвентарний парк 45,9 тис. ваг, або 24,9\% від загального. Майже 10,4 тис. ваг належить державним операторським компаніям (ОК). Парк у розпорядженні УЗ фактично складав 35,5 тис. ваг. Власний парк - 138,8 тис. ваг, або 75,1\% від загального. В Росії утворені 85 дочірніх залежних товариств залізничного транспорту, послуги із надання вагонів під перевезення виконують більше 2200 власників. Частка власного парку складає 91\%.

Постановка проблеми у загальному вигляді та іiї зв'язок із важливими науковими та практичними завданнями. Питання удосконалення системи управління парком власних вантажних вагонів $\epsilon$ важливим для подальшого реформування залізничної галузі України. Компаніями «УВ3-Логістик», Rail Garant та «Спеценерготранс» 3 метою підвищення ефективності керування створене спільне підприємство та об'єднані парки піввагонів. Деякі операторські компанії розглядають можливість злиття 3 кептивними операторами.

Вдалий досвід консолідації парку рухомого складу (сьогодні більше 210 тис. од.) проведений в середині 50-х років минулого століття, коли створена компанія Trailing Train Company (TTC), у яку залізничні перевізники США і Мексики здають свої вагони в керування, повернувши частку вантажів 3 автомобільного транспорту.

Аналіз останніх досліджень i публікацій. В нормативних документах [12] при організації перевезень докладно не враховані застосування методів моделювання для транспортного моніторингу перевезень власним парком операторских компаній. Тому у попередніх дослідженнях [3-7] були розглянуті сучасні підходи до удосконалення технології перевезень парком вагонів операторських компаній. Але потребують розв'язання питання застосування методів моделювання для транспортного моніторингу перевезень власним парком операторських компаній. Адже показники використання власного парку гірші внаслідок неефективних технологій перевезень.

Визначення мети та задачі дослідження. Мета та задачі дослідження застосування методів моделювання для моніторингу перевезень власними парками операторських компаній у взаємодії 3 інфраструктурою і парком вагонів УТЛЦ.

Основна частина дослідження. Загальний парк вагонів в Україні станом на 01.08.2013 р. складав 184,7 тис.ваг, у т.ч.: відповідно, криті - 9,0 тис. ваг, або 4,9\%, платформи - 6,9 тис. ваг, або 3,7\%, напіввагони - 93,6 тис. ваг, або 50,7\%, цистерни - 25,7 тис. ваг, або 13,9\%, рефрижераторні - 0,5 тис. ваг, або 0,3\%, інші - 49,0 тис. ваг, або 26,5\%. Інвентарний парк 45,9 тис. ваг, або 24,9\% від загального, у т.ч.: відповідно, криті - 1,4 тис. ваг, або $15,2 \%$, платформи - 5,9 тис. ваг, або $85,4 \%$, напіввагони - 8,8 тис. ваг, або 9,4\%, цистерни - 9,2 тис. ваг, або 35,8\%, рефрижераторні - 0,1 тис. ваг, або 25,4\%, інші - 20,5 тис. ваг, або 41,9\%. Майже 10,4 тис. ваг належить державним ОК: ДП 


\section{Експлуатація залізниць}

«Український державний центр 3 експлуатації спеціалізованих вагонів» «Укрспецвагон» (УСВ), ДП «Український державний Центр залізничних рефрижераторних перевезень «Укррефтранс» (УРТ), ДП «Український Державний центр транспортного сервісу Ліски» (Ліски), Головне управління колії (ЦП), ДП «Дарницький вагоноремонтний завод» (ДВРЗ), ДП «Стрийський вагоноремонтний завод» (СВРЗ). Таким чином, парк у розпорядженні УЗ фактично складав 35,5 тис.ваг.

Власний парк - 138,8 тис. ваг, або $75,1 \%$ від загального, у т.ч.: відповідно, криті - 7,7 тис. ваг, або 84,8\%, платформи 1,0 тис. ваг, або $14,6 \%$, напіввагони 84,7 тис. ваг, або 90,6\%, цистерни 16,5 тис. ваг, або $64,2 \%$, рефрижераторні 0,4 тис. ваг, або 74,6\%, інші - 28,5 тис. ваг, або 58,1\%. Майже 75,2 тис. ваг, або 40,7\% від загального парку належить державним ОК, у т.ч.: відповідно, криті - 7,2 тис. ваг, або 79,5\%, платформи - 0,6 тис. ваг, або $8,4 \%$, полувагони - 47,3 тис. ваг, або 50,5\%, цистерни - 1,2 тис. ваг, або 4,7\%, рефрижераторні - 0,3 тис. ваг, або 73,1\%, інші - 18,6 тис. ваг, або 38,0\%. Майже 75,2 тис. ваг, або 40,7\% від загального парку належить державним ОК. Всього іншим приватним власникам належить 63,6 тис. ваг, або 34,4\% від загального парку. Аналіз кількості інвентарного і власного парків вагонів в Україні станом на 01.08.2013 р. наведений на рис. 1. Всього в управлінні операторських компаній в Україні станом на 01.08.2013 р. 36,2 тис.ваг.

Парк власних вагонів в управлінні операторських компаній в Україні станом на 01.08.2013 р.: ТОВ «Лемтранс» 14238 ваг, або 39,4\%, ТОВ «Металургтранс» 3989 ваг, або 11,0\%, ПАТ «Укренерготранс» 3585 ваг, або 9,9\%, ДП «ТрансгарантУкраїна» 3557 ваг, або 9,8\%, ДП «Укрспецвагон» 3054 ваг, або 8,4\%, ТОВ «ЕвразТрансУкраїна» 2348 ваг, або 6,5\%, ТОВ «Интерлизинвест» 2224 ваг, або 6,1\%, ТОВ «ЕксІмТранс» 1043 ваг, або 2,9\%, ТОВ «Украинская новая перевозочная компания» 710 ваг, або 2,0\%, ТОВ «Центротранс» 447 ваг, або 1,2\%, ТОВ «Металлургическая транспортная компания» 273 ваг, або 0,8\%, ТОВ «Украинское Промышленное Агентство» 256 ваг, або 0,7\%, ТОВ «ТНТК» 177 ваг, або 0,5\%, ТОВ «Укрметалургтранс» 159 ваг, або 0,4\%, ТОВ «ТЕК «Енерготранс» 113 ваг, або 0,3\%.

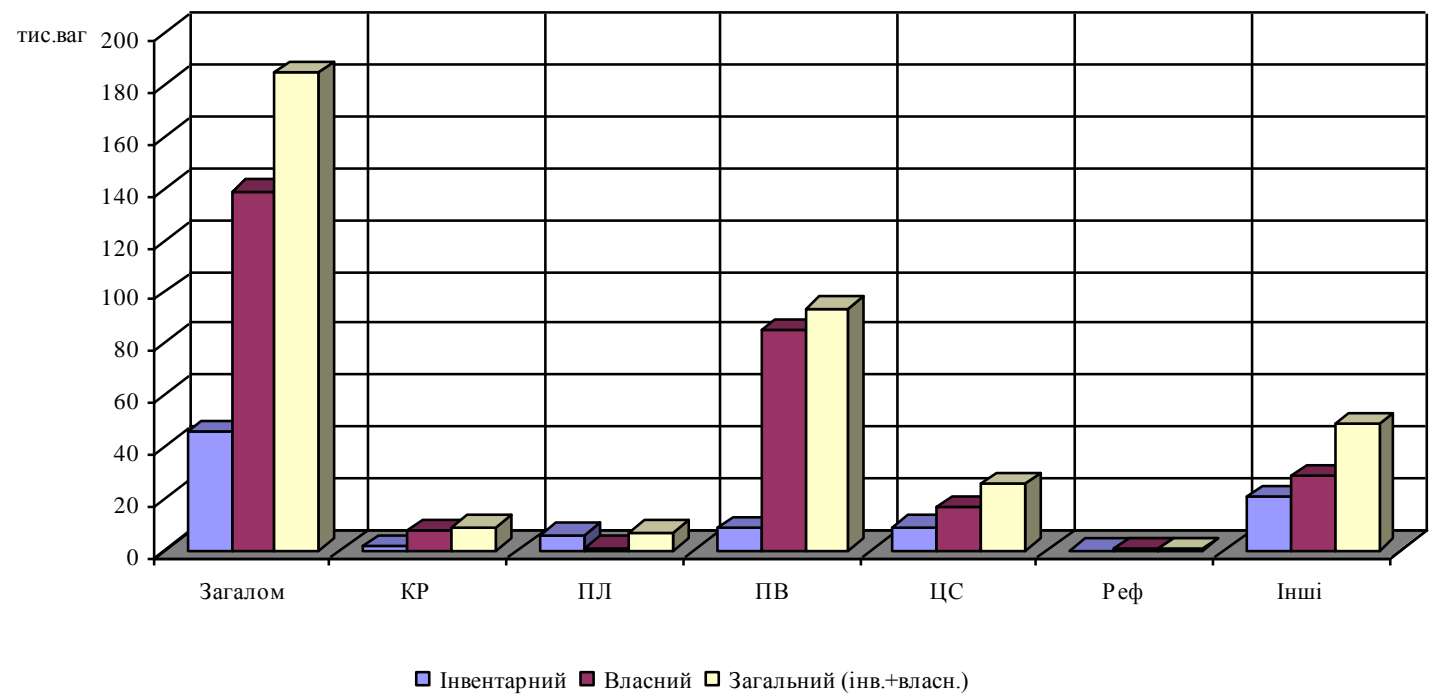

Рис. 1. Аналіз кількості та структури інвентарного і власного парків вагонів в Україні станом на 01.08.2013 p. 
Аналіз кількості та структури парку вагонів в управлінні операторських компаній в Україні станом на 01.08.2013 р. наведено та рис. 2. Керування вагонним парком в Україні здійснює Державне підприємство «Український транспортнологістичний центр» (УТЛЦ). Паралельно із процедурами експлуатації i придбання нового вагонного парку замість списаного ведеться робота 3 наявними та новостворюваними операторами залізничного рухомого складу. Парк вантажних вагонів в управлінні УТЛЦ станом на 01.08.2013 р. становить 59732 ваг, з них криті 6692 ваг, або 11,2\%, напіввагони 44889 ваг, або $75,1 \%$, цистерни 151 ваг, або 0,3\%, рефрижераторні 35 ваг, або $0,1 \%$, інші 7966 ваг, або 13,3\%. У тому числі: УСВ 21957 ваг, або 36,8\%, УРТ 9464 ваг, або $15,8 \%$, Ліски 248 ваг, або $0,4 \%$, ДВР3 24191 ваг, або 40,5\%, СВР3 3871 ваг, або 6,5\%. Аналіз кількості та структури парку вантажних вагонів в управлінні УТЛЦ станом на 01.08.2013 р. наведений на рис. 3.

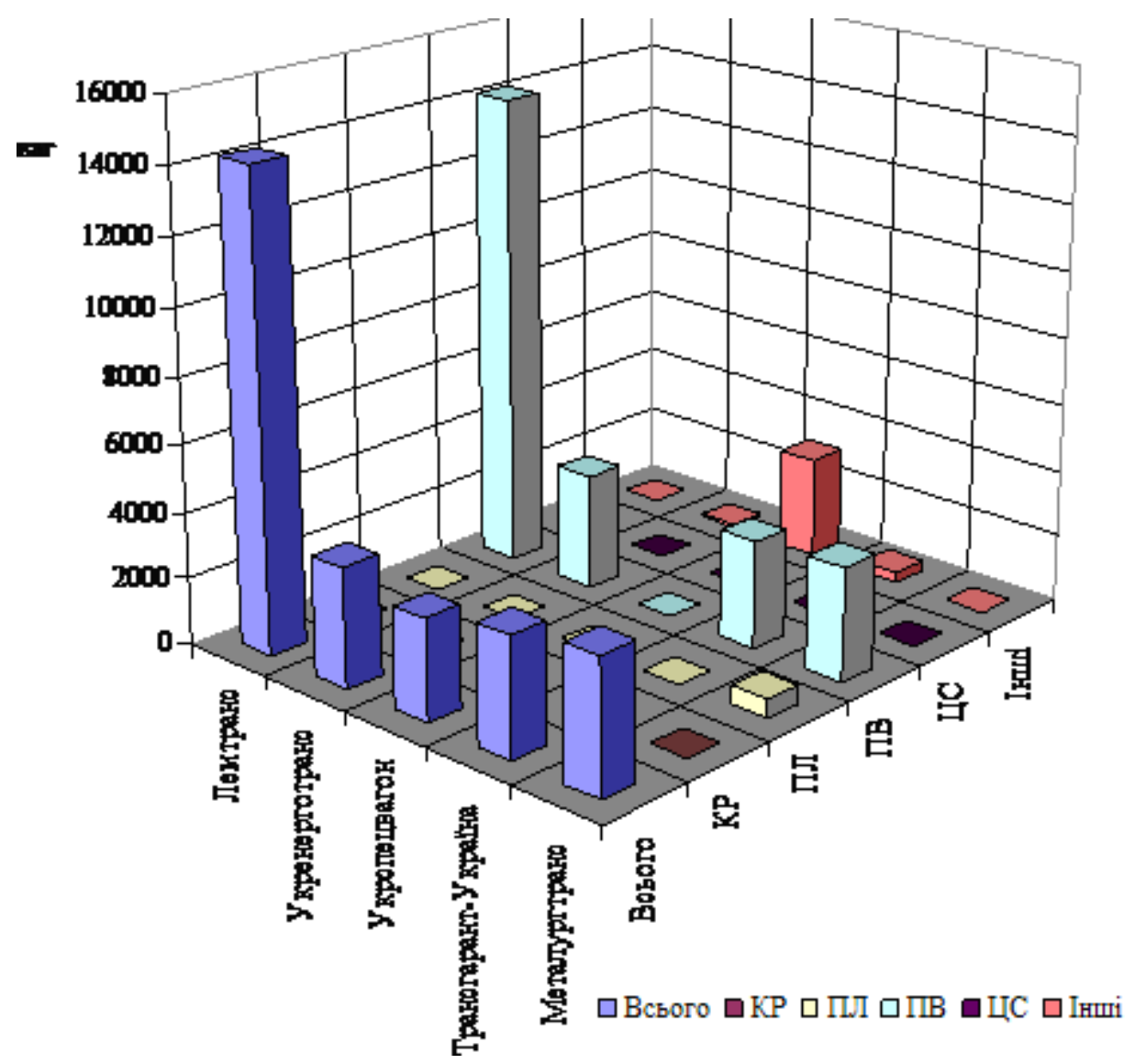

Рис. 2. Аналіз кількості та структури парку вагонів в управлінні операторських компаній в Україні станом на 01.08.2013 р.

Аналіз навантаження 20 операторських компаній України 3 найбільшими обсягами перевень вантажів із 49, з якими укладені договори 3 Укрзалізницею, за 2010-2012 pр. наведений на рис. 4.

У 2012 р. не виконували перевезень: ЗАТ «Укренерготранс» ТОВ «ІНТЕРКАРТРАНС», ООО «Інтертранссервіс», ТОВ «Евратранс
Україна». У той же час реорганізовані або уклали нові договори на перевезенння 31 ОК, у т.ч. найбільші підприємства: ТОВ «Інтерлізінвест», ТОВ «Свразтранс Україна», Корпорація «Міжрегіональний Промисловий Союз», ТОВ «Металургтранс», ТОВ «Лемтранс», ПрАТ «Укренерготранс», ДП «Трансгарант-Украина». 


\section{Експлуатація залізниць}

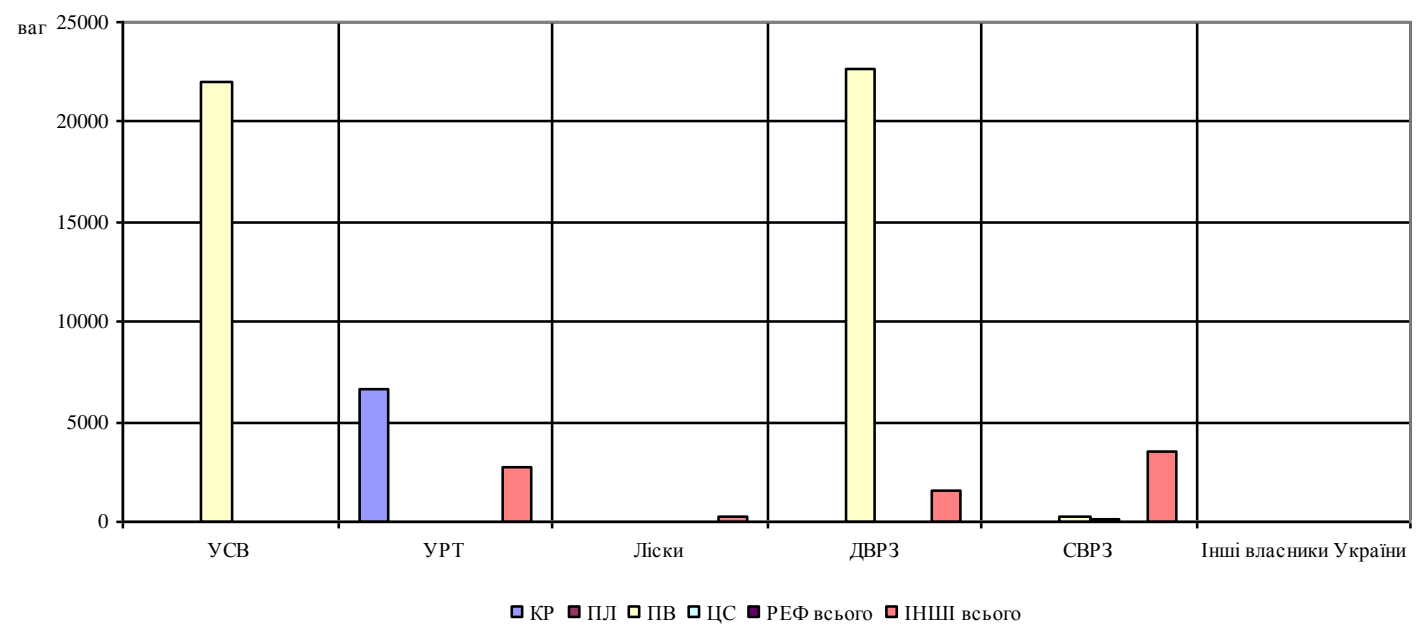

Рис. 3. Аналіз кількості та структури парку вантажних вагонів в управлінні УТЛЦ станом на 01.08.2013 p.

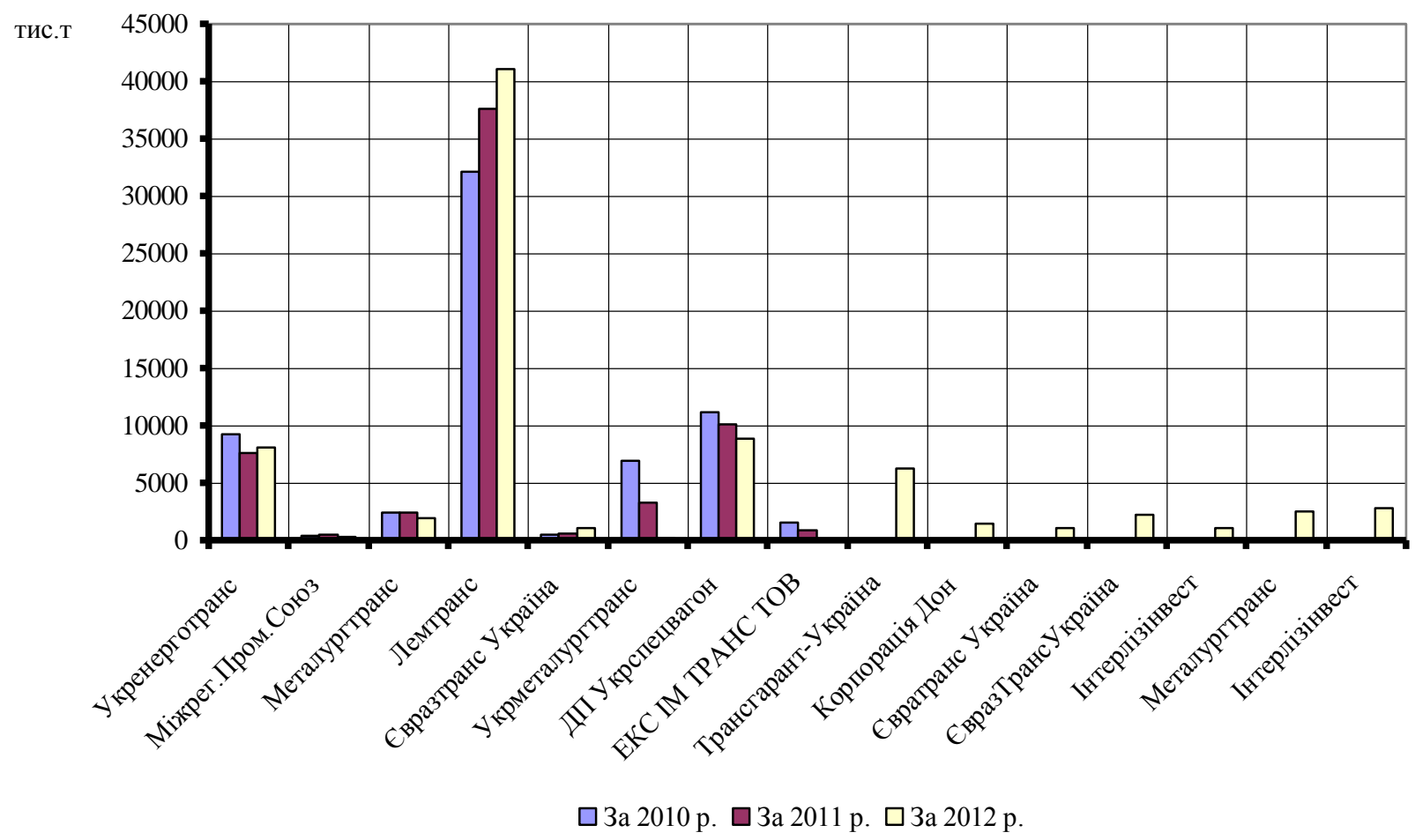

Рис. 4. Аналіз навантаження найбільших операторських компаній України за 2010-2012 pp.

Моделювання моніторингу перевезень власними вагонами парку операторських компаній у взаємодії з інфраструктурою і парком вагонів УТЛЦ, операторів перевезень доцільно реалізувати у вигляді системи імовірнісних автоматів Мура 3 детермінованими функціями виходів. [8] Основні рівняння системи, які визначають внутрішній стан автоматів у дискретні моменти часу $t+1$ як функцій від внутрішнього стану і вхідних сигналів у момент $t$, записані у вигляді стохастичних 
рівнянь. Оскільки система належить до класу систем 3 невизначеною вартістю дефіциту навантажувальних ресурсів (вантажних вагонів операторів перевезень), то критерієм ефективності $\epsilon$ величина забезпеченості системи під навнатаження порожніми вагонами $i$-того виду

$$
C^{(i)}(T)=\frac{Z(T)^{(i)}}{100-D^{(i)}(T)},
$$

де $Z(T)^{(i)}$ - математичне очікування витрат на пошук та перевезення на вантажний фронт $i$-того виду вагонів; $D^{(i)}(T)$ математичне очікування наявності на мережі залізниць $i$-того виду вагонів, у відсотках; $T$ - тривалість входження системи в стаціонарний режим.

Функція $C^{(i)}(T) \quad$ визначається в моделі після входження системи у стаціонарний режим, якщо $t \geq T$.

Величина відносного дефіциту навантажувальних ресурсів (вантажних вагонів операторів перевезень)

$$
D^{(i)}(T)=\frac{\overline{d^{(i)}}(T)}{\overline{\pi^{(i)}}(T)} \cdot 100,
$$

де $\overline{d^{(i)}}(T)$ - математичне очікування кількісного дефіциту $i$-того виду вагонів в системі; $\overline{\pi^{(i)}}(T)$ - математичне очікування попиту $i$-того виду вагонів.

Всі величини в (1), (2) $є$ середньодобовими.

Знаменник у формулі (1) показує забезпеченість системи вагонами $i$-того виду, а величина критерію $C^{(i)}(T)$ вартість $1 \%$ забезпеченості системи. Мінімум критерію $C^{(i)}(T)$ відповідає мінімуму витрат в єдиній системі управління парком вантажних вагонів при умові відносного дефіциту вагонів $D^{(i)}(T)$ у межах $5 \%$ і за мінімумом $C^{(i)}(T)$.

Параметри системи: обсяги вхідних матеріальних потоків - інтенсивність (математичне очікування) потоку навантаження, дисперсія потоку (діапазон математичного очікування величини обсягу вантажів $i$-того виду), період між надходженням; параметри складів вантажовласників - величини мінімальних і максимальних запасів (оптимальні нормативи запасів на складах), місткість накопичувачів складів.

Висновки 3 дослідження i перспективи, подальший розвиток $\mathbf{y}$ даному напрямку. Об'єднання парків різних операторів - серйозний інструмент керування витратами й прибутками. До вигід можна віднести розширення вантажної та клієнтської баз, що дозволяє проводити оптимізацію вагонопотоків, скорочувати витрати i домагатися синергетического ефекту, поліпшення технології роботи, а також удосконалення структури парку рухомого складу.

Розвиток технології гальмує недостатня технічна оснащеність підприємств-вантажовіправників та операторів перевезень. Необхідно побудувати модель фінансування галузі, ввести довгострокову тарифну політику, вирішити питання оптимізації та субсидування збиткових видів діяльності, визначитися із цільовою моделлю ринку.

Варіанти оптимізації керування вагонним парком: поліпшення технологій керування руху рухомого складу, консолідація вантажної бази і користувачів залізничних послуг, спрямована на укрупнення відправлень, маршрутизацію і скорочення порожніх пробігів. 


\section{Список використаних джерел}

1. Транспортна стратегія України на період до 2020 року. Схвалена розпорядженням Кабінету Міністрів України від 16 грудня 2009 р. №1555-р. [Електронний ресурс]. - Режим доступу: www/URL: http://www.mintrans.gov.ua/ uk/discussion/15621.html/ 10.12.2009. - Загол. з екрану.

2. Державна цільова програма реформування залізничного транспорту на 2010-2019 роки. В редакції постанови Кабінету Міністрів України від 26 жовтня 2011 р. № 1106 [Електронний ресурс]. - Режим доступу: www/URL: http://zakon4.rada.gov.ua/laws/show/11062011-п. - Загол. з екрану.

3. Бодюл, В.И. Система управления перевозками грузов для операторов железнодорожного подвижного состава [Текст]/ В.И. Бодюл, А.Н. Феофилов // Наука и техника транспорта. - 2012. - Вып. 1. - С. 57-62

4. Данько, М.I. Визначення парку вагонів операторських компаній для забезпечення перевезень вантажів залізничним транспортом [Текст] / M.І. Данько, В.В. Кулешов // Зб. наук. праць. - Харків: УкрДАЗТ, 2004. - Вип. 57. - С. 121-128.

5. Данько, М.I. Разработка организационно-технологической модели управления парком грузовых вагонов разной формы собственности [Текст] / М.І. Данько, Д.В. Ломотько, В.В. Кулешов // Инновационный транспорт. Научно-публицистическое издание. - 2012. №4(5), - С. 8-13.

6. Данько, M.I. Побудова моделі оцінки інвестицій у залізничну інфраструктуру при взаємодії залізничних адміністрацій та операторів перевезень [Текст] / М.I. Данько, Д.В. Ломотько, В.В. Кулешов // Зб. наук. праць Укр. держ. акад. залізнич. трансп. - Харків: УкрДАЗТ, 2012. - Вип. 134. - С. 7-13.

7. Кулешов, В.В. Удосконалення технології перевезень парком вагонів операторських компаній на станціях вузла [Текст] / В.В. Кулешов, О.Ю. Толбатов, Т.Р. Чурилик // Зб. наук. праць Укр. держ. акад. залізнич. трансп. - Харків: УкрДАЗТ, 2013. - Вип. 135. - С. 107-113.

8. Яровицкий, Н.В. Вероятностные и имитационное моделирование [Текст] / Н.В. Яровицкий, Н.И. Костина // Кибернетика и системный анализ. - 1993. - № 3. - С. $20-30$.

Рецензент д-р техн. наук, професор Є.С.Альошинський

Кулешов Валерій Вячеславович, канд. техн.наук, доцент кафедри залізничних станцій та вузлів Української державної академії залізничного транспорту. Тел.: (057) 730-10-42. E-mail: kharkov-kuleshov@ mail.yandex.ua

Valery Kuleshov V., Ph.D., dotsent cafedra railway stations and junctions Ukraine State Academy of Railway

Transport.. Tel.: (057) 730-10-42. E-mail: kharkov-kuleshov@mail.yandex.ua 